NASA Technical Memorandum 105385

\title{
CVD of Silicon Carbide on Structural Fibers: Microstructure and Composition
}

Lisa C. Veitch, Francis M. Terepka, and Suleyman A. Gokoglu Lewis Research Center

Cleveland, Ohio

\section{Prepared for the}

1991 Fall Meeting of the Materials Research Society

Boston, Massachusetts, December 2-6, 1991 


\title{
CVD OF SILICON CARBIDE ON STRUCTURAL FIBERS:
}

\section{MICROSTRUCTURE AND COMPOSITION}

\author{
Lisa C. Veitch, Francis M. Terepka, Suleyman A. Gokoglu \\ National Aeronautics and Space Administration \\ Lewis Research Center \\ Cleveland, Ohio 44135
}

\section{SUMMARY}

Structural fibers are currently being considered as reinforcements for intermetallic and ceramic materials. Some of these fibers, however, are easily degraded in a high temperature oxidative environment. Therefore, coatings are needed to protect the fibers from environmental attack.

Silicon carbide (SiC) was chemically vapor deposited (CVD) on Textron's SCS6 fibers. Fiber temperatures ranging from 1350 to $1500{ }^{\circ} \mathrm{C}$ were studied. Silane $\left(\mathrm{SiH}_{4}\right)$ and propane $\left(\mathrm{C}_{3} \mathrm{H}_{8}\right)$ were used for the source gases and different concentrations of these source gases were studied. Deposition rates were determined for each group of fibers at different temperatures. Less variation in deposition rates were observed for the dilute source gas experiments than the concentrated source gas experiments. A careful analysis was performed on the stoichiometry of the CVD SiC-coating using electron microprobe. Microstructures for the different conditions were compared. At $1350{ }^{\circ} \mathrm{C}$, the microstructures were similar; however, at higher temperatures, the microstructure for the more concentrated source gas group were porous and columnar in comparison to the cross sections taken from the same area for the dilute source gas group.

\section{INTRODUCTION}

Ceramic fibers are of interest as reinforcing materials for advanced ceramic and intermetallic matrix composites for aerospace applications. For many of these commercially existing fibers, additional coatings will be needed to protect the fibers from oxidation. These coatings will also serve to enhance the fiber/matrix interfacial properties.

Silicon carbide coating has been considered to protect the outer carbon-rich coatings of Textron Specialty Materials' SCS6 silicon carbide fiber and can be synthesized by chemical vapor deposition (CVD) techniques. A number of different precursors, conditions and reactors have been discussed in the literature (refs. 1 to 3 ). In this work, the deposition rates, stoichiometry and microstructure of the CVD SiC on SCS6 was examined.

\section{EXPERIMENTAL}

For the deposition experiment, a vertical batch fiber reactor was used to coat $30 \mathrm{~cm}$ long fibers (ref. 4). Deposition temperatures ranged from 1350 to $1500{ }^{\circ} \mathrm{C}$, and $\mathrm{SiH}_{4}$ and $\mathrm{C}_{3} \mathrm{H}_{8}$ were used as the source gases with $\mathrm{H}_{2}$ as the carrier gas. A 1:9 Si:C atom ratio of source gases was held constant for all deposition experiments. Two distinct sets of experiments were conducted, based on different source gas concentrations. Group A experiments were performed using $3 \mathrm{~mol} \% \mathrm{SiH}_{4}$ and $9 \mathrm{~mol} \% \mathrm{C}_{3} \mathrm{H}_{8}$. Group B experiments were conducted using $0.3 \mathrm{~mol}_{0} \mathrm{SiH}_{4}$ 
and $0.9 \mathrm{~mol} \% \mathrm{C}_{3} \mathrm{H}_{8}$. The temperature of the fibers during the CVD process was monitored at the center $(15 \mathrm{~cm})$ of the fiber with a two-colored optical pyrometer.

\section{RESULTS AND DISCUSSION}

The CVD SiC coating thickness on the fibers was measured using a split image microscope. SEM micrographs of polished cross sections were also used from several locations along each fiber to confirm the optical microscope readings. Figures 1 and 2 show the deposition rate variation along the fibers for different temperatures for each group. The error bars indicate the standard deviation in deposition rate measurements. A large variation in SiC thickness and, hence, deposition rate was evident for the group A fibers. For the dilute source gas case for group B fibers, less variation was seen. It is possible that the Si atoms are able to migrate over a longer range on the surface of the fiber for dilute flows before becoming incorporated in the surface as SiC. This would give a more uniform profile along the fiber.

It is difficult to conclude what are the dominant mechanisms for this particular SiC CVD process. The flat profile for group B fibers may be evidence of diffusion controlled process. The large rates at the beginning of the skewed profile for the group A fibers may be explained by a thermally controlled chemical kinetic process and, then, farther along the fiber, the process seems to have become more diffusion and depletion controlled. However, for both groups, there are a number of different decomposition reactions occurring during the CVD process and, what species are available and at what concentration is not known. The uncertainties in the fiber temperature measurement will also contribute to the observed scatter in the deposition rate data (ref. 4).

Electron microprobe analysis was used to determine the stoichiometry of the SiC coating. CVD single crystal beta-SiC was used as a standard. The fiber samples analyzed were taken from the center position of the fibers where the temperature was monitored. Figures 3 and 4 show the variation in stoichiometry for the different temperatures for each group. For group A fibers, the $\mathrm{SiC}$ deposited at $1350{ }^{\circ} \mathrm{C}$ was only $3 \mu \mathrm{m}$ thick and resulted in an unreliable chemical analysis. The measurement error for the electron microprobe analysis is $\sim 10$ percent. From figures 3 and 4, all of the fiber coatings fall within the electron microprobe error. For this reason, all of the $\mathrm{SiC}$ coatings can be considered close to stoichiometric.

Several places along the fibers from each of the groups were also analyzed. At $1400{ }^{\circ} \mathrm{C}$, the Si-rich $\mathrm{SiC}$ coating became more stoichiometric from the $17 \mathrm{~cm}$ position to the end of the fiber $(30 \mathrm{~cm})$, and by $1500{ }^{\circ} \mathrm{C}$, the CVD SiC coating became stoichiometric as early as the $7 \mathrm{~cm}$ position (close to the gas inlet). A similar trend was observed for the group B fibers also. One can explain this by the fact that $\mathrm{C}_{3} \mathrm{H}_{8}$, which is harder to crack than silane, starts to dissociate faster at higher temperatures into more reactive species, such as $\mathrm{CH}_{3}, \mathrm{C}_{2} \mathrm{H}_{5}, \mathrm{C}_{2} \mathrm{H}_{4}$ and $\mathrm{C}_{2} \mathrm{H}_{2}$, and becomes competitive with Si-containing species for the formation of $\mathrm{SiC}$ (ref. 3 ).

SEM micrographs (backscatter and secondary electron) revealed that the microstructures of the higher temperature CVD SiC for group A fibers was columnar and less dense than that of the higher temperature cases for group B fibers. Figure 5 shows the $1450{ }^{\circ} \mathrm{C}$ cases for each group (the cross sections are taken from the center position of the fibers). This type of growth can be attributed to the fact that the group B fibers have a much slower deposition rate than the group A fibers. Similar morphologies with other precursors have been reported for these 
temperatures (refs. 1 and 3). Close to the gas inlet position, both fiber groups exhibited a very porous and columnar structures for temperatures between 1400 and $1500{ }^{\circ} \mathrm{C}$.

Figure 6 compares the microstructures for the $1350{ }^{\circ} \mathrm{C}$ cases. Here, the microstructures appear similar. It seems that temperature, rather than deposition rates, is the critical variable in determining the microstructure evolving at $1350{ }^{\circ} \mathrm{C}$.

\section{SUMMARY}

Silicon carbide was deposited on Textron's SCS6 fiber using $\mathrm{SiH}_{4}$ and $\mathrm{C}_{3} \mathrm{H}_{8}$ precursors. The deposition rates for temperatures ranging from 1350 to $1500^{\circ} \mathrm{C}$ and different source gas concentrations were determined. Electron microprobe analysis was used to determine the stoichiometry along the fibers. The CVD SiC coatings were close to stoichiometric for all of the temperatures and source gas concentrations studied. Also, at higher deposition temperatures, the $\mathrm{SiC}$ coatings were more stoichiometric along longer lengths of the fiber. The microstructure of the $\mathrm{SiC}$ coatings were compared. At $1350{ }^{\circ} \mathrm{C}$, the microstructures were similar; however, at higher temperatures, the microstructure for the more concentrated source gas group were porous and columnar in comparison to cross sections taken from the same area for the dilute source gas group.

\section{REFERENCES}

1. Choi, B.J.; and Kim, D.R.: Growth of Silicon Carbide by Chemical Vapor Deposition. J. Mater. Sci. Lett. vol. 10, 1991, pp. 860-862.

2. Saigal, A.; and Das, N.: Effect of Deposition Parameters on the Strength of CVD Beta-SiC Coatings. Adv. Ceram. Mater., vol. 3, no. 6, 1988, pp. 580-583.

3. Niihara, K.; Suda, A.; and Harai, T.: Preparation and Mechanical Properties of CVD-SiC. Proceedings of the International Symposium on Ceramic Component for Engine, Hakone, Japan, 1983, pp. 480-489.

4. Gokoglu, S.A., et al.: A Numerical and Experimental Analysis of Reactor Performance and Deposition Rates for CVD on Monofilaments. Chemical Vapor Deposition, K.E. Spear and G.W. Cullen, eds., Pennington Publ., 1990, pp. 31-37. 


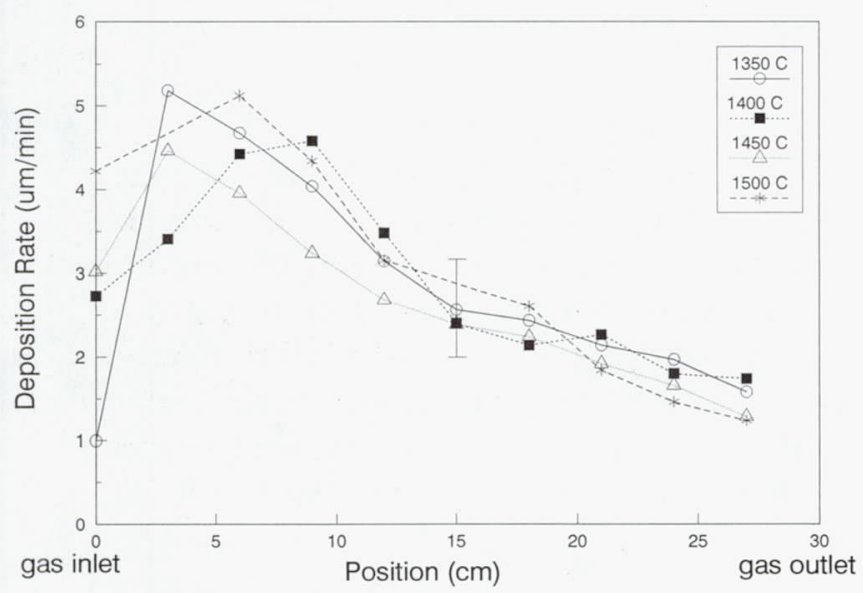

Figure 1.-Deposition rate vs. position for Group A.

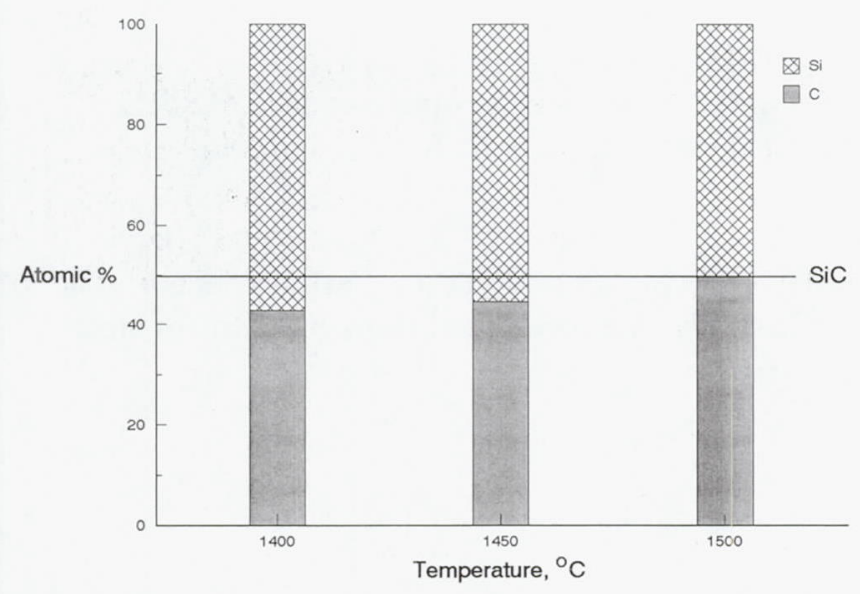

Figure 3.-Electron microprobe analysis of CVD SiC (Group A).

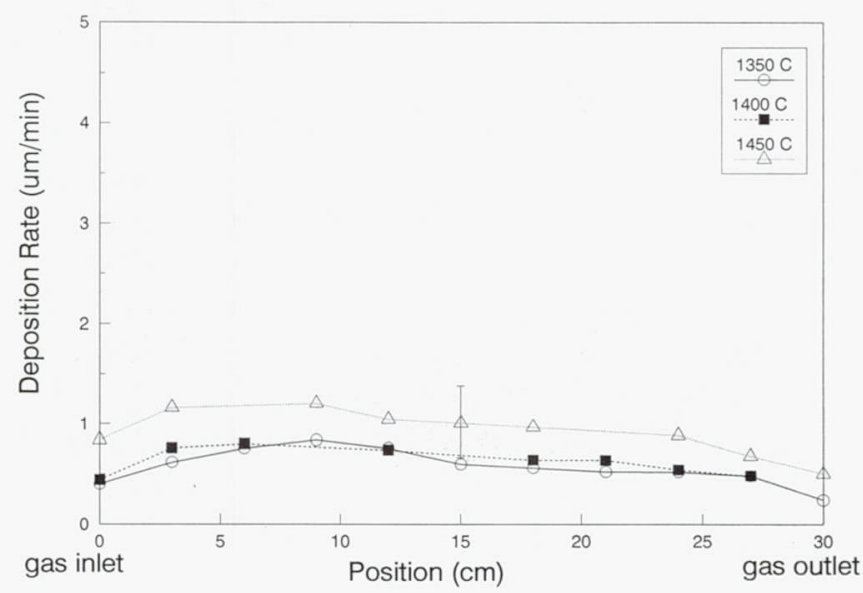

Figure 2.-Deposition rate vs. position for Group B.

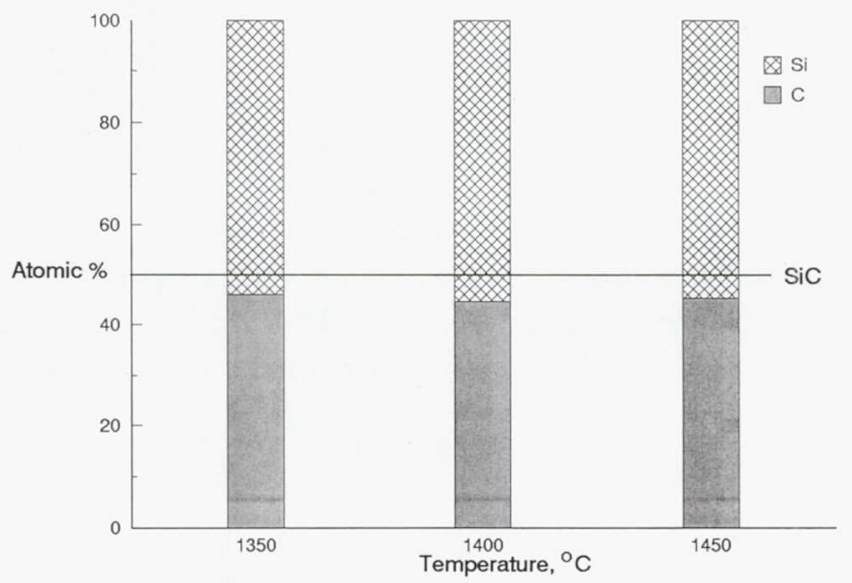

Figure 4.-Electron microprobe analysis of CVD SiC (Group B). 


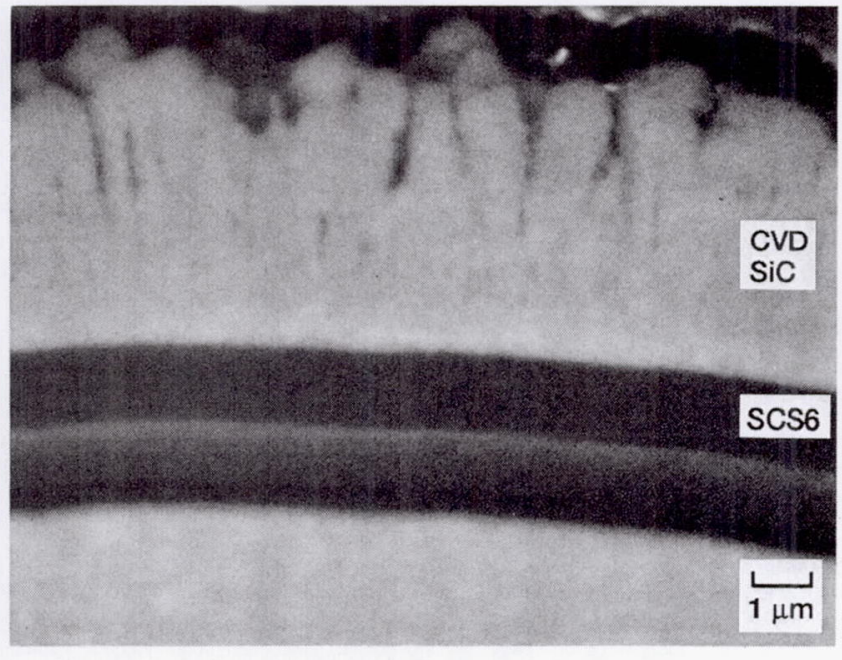

(a) Group A.

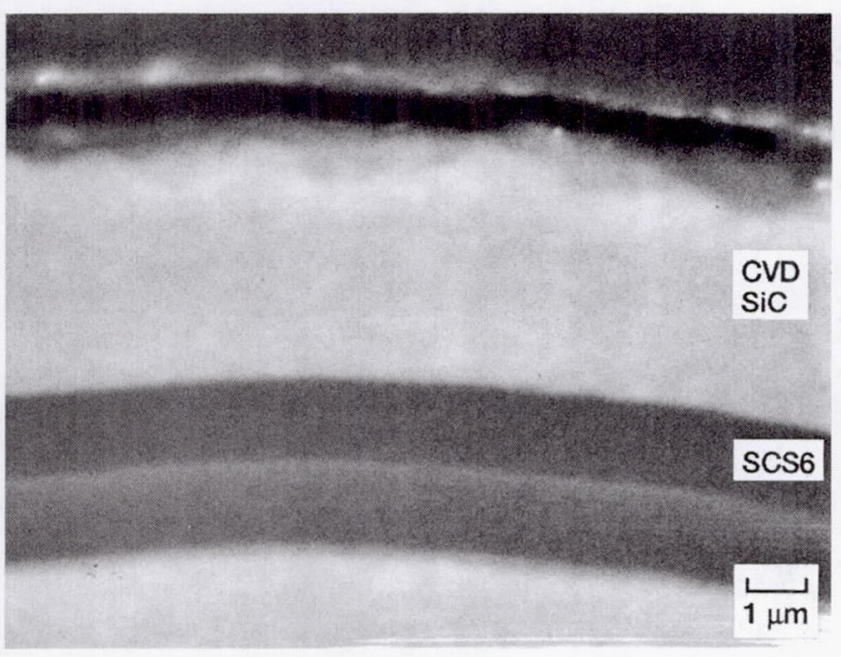

(b) Group B.

Figure 5.- SiC coatings on SCS6 deposited at $1450^{\circ} \mathrm{C}$.

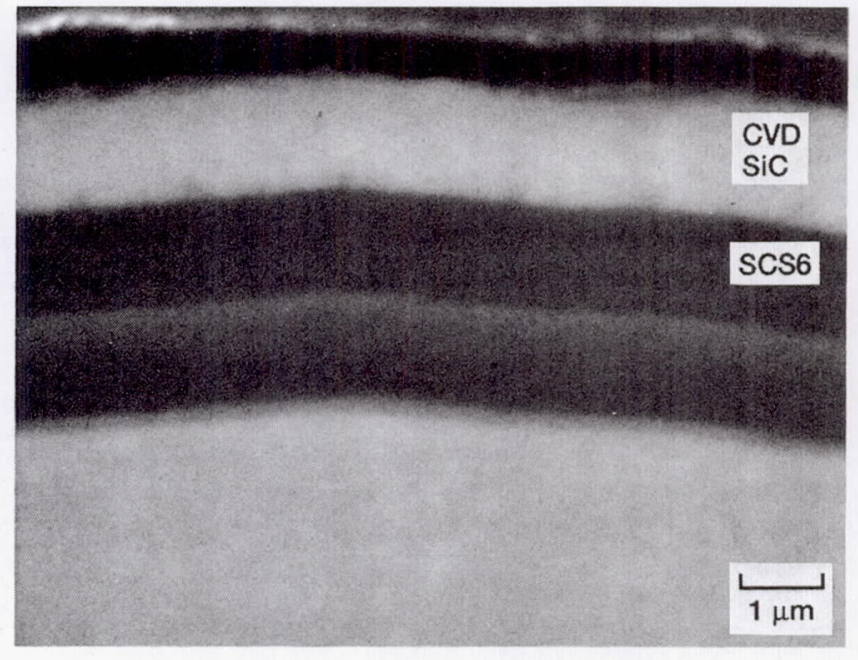

(a) Group A.

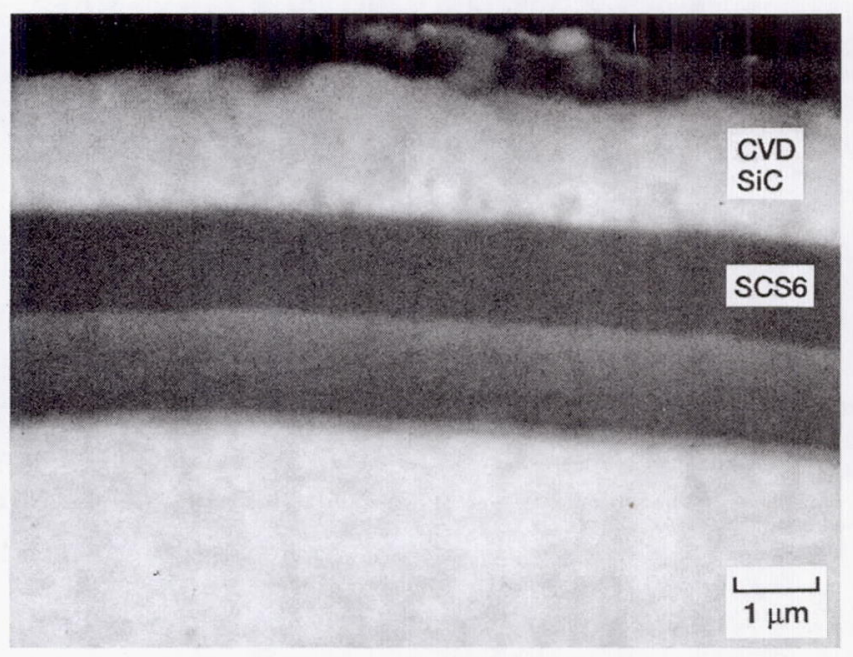

(b) Group B.

Figure 6.-SiC coatings on SCS6 deposited at $1350^{\circ} \mathrm{C}$. 
Public reporting burden for this collection of information is estimated to average 1 hour per response, including the time for reviewing instructions, searching existing data sources, gathering and maintaining the data needed, and completing and reviewing the collection of information. Send comments regarding this burden estimate or any other aspect of this collection of information, including suggestions for reducing this burden, to Washington Headquarters Services, Directorate for information Operations and Reports, 1215 Jefferson Davis Highway, Suite 1204, Arlington, VA 22202-4302, and to the Office of Management and Budget, Paperwork Reduction Project (0704-0188), Washington, DC 20503.
1. AGENCY USE ONLY (Leave blank) 2. REPORT DATE
1992 3. REPORT TYPE AND DATES COVERED
Technical Memorandum

4. TITLE AND SUBTITLE

CVD of Silicon Carbide on Structural Fibers: Microstructure and Composition

6. $\operatorname{AUTHOR}(\mathrm{S})$

Lisa C. Veitch, Francis M. Terepka, and Suleyman A. Gókoglu

WU-510-01-01

7. PERFORMING ORGANIZATION NAME(S) AND ADDRESS(ES)

National Aeronautics and Space Administration

Lewis Research Center

Cleveland, Ohio 44135-3191

8. PERFORMING ORGANIZATION REPORT NUMBER

E-6770

9. SPONSORING/MONITORING AGENCY NAMES(S) AND ADDRESS(ES)

10. SPONSORING/MONITORING AGENCY REPORT NUMBER

National Aeronautics and Space Administration

Washington, D.C. 20546-0001

NASA TM-105385

11. SUPPLEMENTARY NOTES

Prepared for the 1991 Fall Meeting of the Materials Research Society, Boston, Massachusetts, December 2-6, 1991.

Responsible person, Lisa C. Veitch, (216) 433-3167.

12a. DISTRIBUTION/AVAILABILITY STATEMENT

12b. DISTRIBUTION CODE

Unclassified - Unlimited

Subject Category 24

13. ABSTRACT (Maximum 200 words)

Structural fibers are currently being considered as reinforcements for intermetallic and ceramic materials. Some of these fibers, however, are easily degraded in a high temperature oxidative environment. Therefore, coatings are needed to protect the fibers from environmental attack. Silicon carbide (SiC) was chemically vapor deposited (CVD) on Textron's SCS6 fibers. Fiber temperatures ranging from 1350 to $1500{ }^{\circ} \mathrm{C}$ were studied. Silane $\left(\mathrm{SiH}_{4}\right)$ and propane $\left(\mathrm{C}_{3} \mathrm{H}_{8}\right)$ were used for the source gases and different concentrations of these source gases were studied. Deposition rates were determined for each group of fibers at different temperatures. Less variation in deposition rates were observed for the dilute source gas experiments than the concentrated source gas experiments. A careful analysis was performed on the stoichiometry of the CVD SiC-coating using electron microprobe. Microstructures for the different conditions were compared. At $1350^{\circ} \mathrm{C}$, the microstructures were similar; however, at higher temperatures, the microstructure for the more concentrated source gas group were porous and columnar in comparison to the cross sections taken from the same area for the dilute source gas group.

\begin{tabular}{|c|c|c|c|}
\hline \multicolumn{4}{|c|}{ 14. SUBJECT TERMS } \\
\hline \multicolumn{4}{|c|}{ Silicon Carbide; CVD; Silicon carbide fibers } \\
\hline 17. & $\begin{array}{l}\text { SECURITY CLASSIFICATION } \\
\text { OF REPORT } \\
\text { Unclassified }\end{array}$ & $\begin{array}{l}\text { 18. SECURITY CLASSIFICATION } \\
\text { OF THIS PAGE }\end{array}$ & $\begin{array}{l}\text { 19. SECURITY CLASSIFICATION } \\
\text { OF ABSTRACT }\end{array}$ \\
\hline & Unclassinied & Unclassified & Unclassified \\
\hline
\end{tabular}



National Aeronautics and

Space Administration

Lewis Research Center

Cleveland, Ohio 44135

Otficial Business

Penalty for Private Use $\$ 300$
FOURTH CLASS MAIL

ADDRESS CORRECTION REQUESTED
||||| U.S.MAIL

Postage and Fees Paid National Aeronautics an Space Administration NASA 451 